\title{
Analysis of Electricity Demand to Increase the Electrification Ratio (Case Study: Madura Island)
}

\author{
Addin Aditya ${ }^{1}$, Erma Suryani ${ }^{1}$, and Rully Agus Hendrawan ${ }^{1}$
}

\begin{abstract}
One of the Indonesia's problem as an archipelago is uneven electrification ratio in the entire of archipelago. Especially for small and isolated island are not effectively to build a large power plant due the ratio between population and investment are immense. In here, a strategy to increase the electrification ratio in the islands is a challenge for Indonesia Government. In this research will be used the dynamic model approach to analyze the demand of electrical energy in Madura Island to increase the electrification ratio in the Indonesia's Islands. The result shows that the growth of electricity demand in Madura Island is $9 \%$ and the most important factor that affecting electrification ratio in Madura is number of electricity customer and power plant capacity to increase the electrification ratio.
\end{abstract}

Keywords- System Dynamic, Electricity Demand, Electrification Ratio, Power Plant Capacity.

\section{INTRODUCTION}

Energy was the main requirement throughout the human civilization. Growth of energy needs could be the indicator of the prosperity in an area. But at the same moment, it created another problem about how to supply the energy. The Electric energy was one of the most important human need. Both household and business need electric power. As an archipelago country, Indonesia has the challenge of inequality of electrification ratio. According to Ministry of energy and mineral resource (2014), currently there are 14 province in Indonesia that have the electrification ratio above $60 \%$. Which is Aceh (76.98\%), North Sumatera (69.68\%) West Sumatera (69.37\%), Bangka Belitung (72.88\%), Banten (63.9\%), Jakarta (100\%), West Java (67.4\%), Central Java (71.24\%), Yogyakarta (84.48\%), East Java (71.55\%), Bali (74.98\%), East Kalimantan (68.56\%), South Kalimantan (72.29\%) and North Sulawesi (66.87\%), another province have about $41 \%-60 \%$ of electrification ratio. Which is Riau (55.84\%), Jambi (51.41\%), Bengkulu (51.46\%), Lampung (48.82\%), South Sumatera (50.30\%), West Kalimantan (45.83\%), Central Kalimantan (45.22\%), Gorontalo (49.79\%), Central Sulawesi (48.30\%), West Sulawesi, South Sulawesi (55.2\%), Maluku (54.51\%) and North Maluku (49.44\%) and the rest have 20\% - 40\% of electrification ratio. Namely West Nusa Tenggara $(32,51 \%)$, East Nusa Tenggara $(24.55 \%)$, Southeast Sulawesi (38.09\%) and also Papua and East Irian $(32.35 \%)$. The larger island such as Java and Sumatera could build a number of large power plant and distribute it with economics scale. While Small Island are very uneconomical to build a number of large power plant

${ }^{1}$ Addin Aditya, Erma Suryani, and Rully Agus Hendrawan are with Departement of Physics, Institut Teknologi Sepuluh Nopember, Surabaya, Indonesia. E-mail: addinaditya@gmail.com; erma.suryani@gmail.com; eraha@its-sby.edu. because ratio of investment cost by the number of population is too large. Madura Island was the region with the lowest electrification ratio in East Java, which is about $49.7 \%$. This is because of the topographical conditions in Madura, which is the small number of household in the village while the distance between the villages is also quite far. This year, according to deputy manager of communication and environment development PT PLN (Persero) East Java distribution that they will increasing the electrification ratio up to $77.16 \%$. To reach it, PT PLN will do some programs. Such as lisdes (listrik pedesaan) and accelerate the installation for new customer. Until now, electricity of Madura Island still depend from Java electricity supply through 150.000 volt high voltage sea circuit cable with capacity 2 x $100 \mathrm{mw}$, which is lie from Gresik to Kamal, Madura. These transmission cable must through Madura Strait which often traveled by ship and prone to damage the cable. Now, PT PLN (Persero) was already running Natural Gas Power Plant, it have 2 x 18 mw capacity in East Gili, Bangkalan Regency to anticipate if the transmission have some trouble. According to PT PLN (Persero), there were 395.000 of customer electricity spread in Bangkalan, Pamekasan, Sampang and Pamekasan regency with growth up to $2 \%$.

The reason why we used system dynamics is because system dynamics has more advantages than another conventional forecasting methods. System dynamics could gave a better forecasting than statistic model. Dynamic system give way to understanding the behaviour of industrial stakeholder and determining what factors that forecasting the behaviour with significant and sensitively.

This research aims to increasing the electrification ratio in Madura Island based on number of electricity customer and power plant capacity for each regency in Madura Island and projected the electricity demand on Madura Island with growth 9\% (PT. PLN).

\section{A. Related Research}

Supply of electric energy from PT PLN (Persero) still couldn't fulfill the human needs of electricity because of geographic condition of Indonesia. On the previous research, Anwar (2011) said that Madura electricity supplied from Gresik to Kamal, Madura Island through 1 circuit cable with $120 \mathrm{mw}$ capacity. Electric energy have an important role to Indonesia's economic. Dearth of electricity supply will forced PT PLN to do extinguishing. According to Axella (2012), there are several variables that can defined in the plan generation systems, including: generating capacity, consumer electrical capacity, electrical energy demand, fuel prices, load factor, forced outage rate and capacity factor. Saptari (2014) said that by 
utilizing system dynamics can be inferred level of customer satisfaction on electrical energy.

\section{METHOD}

\section{A. Steps to Develop System Dynamics}

This research will be done in several steps following in figure 1. This research start with literature studies based on textbooks, journals and other scientific articles that related to power system. Then we construct all variables that related to electricity demand and electrification ratio. Next we develop causal loop diagram if it's appropriate with existing condition. Continued with developing mathematics model and specification model. And we do validation, verification and scenario. Last part, we analyze the scenario and give the conclusion.

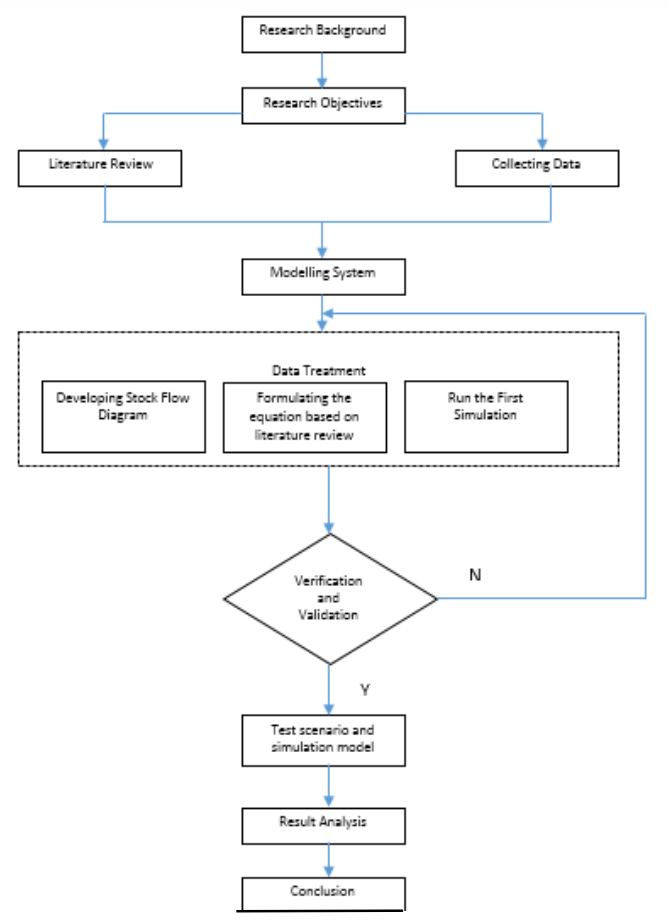

Figure 1. Research Flow

\section{B. Assumption Used in Projecting Electricity Demand}

According to Indonesia Constitution Number 30 chapter 28 and 29 year of 2009 about electricity, PT PLN as the owner of the license for electricity supply business for public has responsibility to supply enough, good quality and reliable electric energy continuously. Therefore PLN must be able to serving the electricity demand now or future. As a start, PLN must be able to projecting electricity demand for next ten years.

Refers to RUPTL PLN (2015-2024), electricity demand in an area influencing in three main factors, which is economic growth, electrification program and movement of captive power to PLN grid. Economic growth in simple definition is a process to increasing output of goods and services. Besides, the impact of economic growth is enhancement of society income which is pushing enhancement of electricity demand.

Second factor is electrification program. As an effort to support government's program to increasing the electrification ratio, PT PLN had to give electricity to all people who include in their work environment. PLN is planning to add new electricity customer, approximately
2.1 billion per year, so that the electrification ratio will raise to $99.4 \%$ in 2024 .

Last factor is captive power transfer (the use of independent power plant with fuel resource) become PLN customer. This is because PLN couldn't fulfill the demand in an area. When the ability to fulfill the demand is raising, then captive power will turn to PLN customer.

\section{Power System}

Marsudi (2011) said that most of power system running by turning the synchronous generator so it can get the electricity power with three phase voltages. The machine to turn the generator usually use with: diesel, steam turbine, water resource and natural gas. This machines get the power from fuel or from waterfall.

Power system is a place where generation of electricity process is done. Remembering that electric generation is a conversion form primary energy (fuel or water resource) to mechanical energy, which is next this mechanical energy will become electric energy by the generator. There are many kind of power generation:

- Hydroelectric Power Plant: this power system use water resource as their primary energy

- Steam Power Plant: this power system using coal, oil or gas as their primary energy.

- Natural gas Power Plant: this power system use natural gas as their primary energy.

- Combined Cycle Power System: this power system is combination between natural gas and steam power plant. Wasted gas from natural gas power plant is used to producing steam from steam boiler to turn the turbine

According to Sutrisna \& Rahardjo (2009), in choosing the type power plant, we need to consider a few criteria. Which is annual load growth prediction, load curve characteristic, power system reliability, primary resource availability and price, environment aspect, social and politics aspect.

- The amount of generated electricity energy must fulfill the load demand at the same time. There are three kind of power plant based on their operation time. Base Load Power Plant is type of power plant that handle the constant base load. Intermediate Power Plant is type of power plant usually used to covering base load in load curve anytime. The last is Peak Load Power Plant which it will operated if PT PLN face the peak load.

- A lot of factor that became reliability and quality parameter of electricity. Namely, unstable frequency, voltage fluctuation, interruption. For first and second parameter, commonly they have problems in transmission or distribution. While the last parameter, usually in generation sector, because it related to fulfill the supply capacity to load. Usually the method that used to determining that index is LOLP (Loss of Load Probability) or LOLE (Loss of Load Expectation). LOLP is a method to measure the power system reliability with considering the probability if a power system can't covering the load perfectly. There are many failure that happened in power generation because of there are no availability of primary resource. This problem often happened in fuel resource power generation. 
- The government's policy on research and development in energy and people's needs has to be appropriate to ensure the national energy planning in the future.

- Economic aspect of power plant commonly covering in three big things. First investment cost, operational cost, maintenance of power generation cost. Economic aspect of power system can be seen from electricity price from every $\mathrm{kWh}$ (Kilowatt Hour). One of factors influencing that economic-power system is fuel cost. Commonly, fuel cost to fuel resource power plant is $80 \%$ from power plant built cost and for nuclear power plant is $50 \%$ from power plant built cost.

- System must appropriate with geographic condition and international affairs. Building power plant refers to geographical condition and what effect can be caused to other country. For example, operation of steam power plant producing $\mathrm{CO}_{2}$ to the air. Controlling of $\mathrm{CO}_{2}$ is necessary for other country. At this aspect, need an international cooperation to ensure a reliability and good environmentally system.

\section{Related Factors of Power Plant}

Quoted from Marsudi (2011), there are 3 main factors that related to power plant:

- Load Factor

Load factor is comparison between the number of average load in an interval time with peak load in same time. Electricity demand is the number of electricity power's need which is expressed in $\mathrm{KWh}$, KW or KVA depends on its context. The electricity producer wants to the highest load factor, because more high the load factor, it means they can use the power system's tool much better. In practically, the load factor around $60 \%-80 \%$.

- $\quad$ Forced Outage Rate (FOR)

FOR is a factor that give the information about how often a power plant disturbance. Annual forced outage rate for hydroelectric power plant is around $1 \%$. While forced outage rate for steam power plant is around 0.5 to 0.1 . More reliable a power plant, so the number of FOR will smaller.

- Capacity Factor

Capacity factor is comparison between real production and maximum capacity production in one period. In practically, annual capacity factor for steam power plant is up to $60 \%-80 \%$.

\section{E. System Dynamic}

Dynamic system is a computerized approach to analyze and designing a policy. Literally, every dynamic system characterized by dependency, mutualism interaction, feedback and causal loop. Dynamic system is starts from research identification dynamically, continued with mapping and modelling the significant variables. After that, stock and flow diagram development. At this step, we identifying the rate in or level in system and rate out. Next step is developing model and simulated then collecting applicable understanding and policy from the result.

Model is represented from the real system in a real world. You can say a good model if the behavior in the model is similar with the real system. Winardi (1989) said that developing a model is influencing by subjectivity of person or organization. Because of that, it need to be enhanced with more information and relevant potential.

Adapted from Barlas (1996), the advantages using model to do the research with system approach is:

\section{Allows to do some research with many topics}

- You can do some experiment without giving any specific behavior to system

- Allows to determining the objective of management activity and repair of the system

- Can use to forecast the behavior and condition of system for future.

Validation is a process to determining are the conceptual model reflecting the real system properly or not (Forrester, 1968). There are two ways to testing the validation of model:

1) Mean Comparison

Where:

$$
E 1=\frac{\lfloor\bar{S}-\bar{A}\rfloor}{\bar{A}}
$$

$$
\begin{aligned}
& \bar{S}=\text { Value_of_Average_Simulation_result } \\
& \bar{A}=\text { Value_of_Average_Data }
\end{aligned}
$$

Model valid if $\mathrm{E} 1 \leq 5 \%$

\section{2) Error Variance}

Where:

$$
E 2=\frac{|S s-S a|}{S a}
$$

Ss: Standard Deviation of Model

Sa: Standard Deviation of data

Model valid if E2 $\leq 30 \%$

\section{RESULTS AND DISCUSSION}

\section{A. Data}

This research used data of electricity demand from PT PLN. Electricity demand is total of electric energy demand in a year in Madura Island in $\mathrm{kWh}$ (Kilowatt Hours)

Electricity demand growth is growth of electricity demand in Madura Island, expression in \%.

Reserve margin is reserve power from power plant against peak load, represented in \%

Electrification ratio is comparison between number of electricity customer and total of population in Madura Island.

Demand forecast is forecasting of Madura Island's load until 2040.

\section{B. Identify Related Variables}

Based on the research objectives, can be seen in table 1, several variables that related to the research objectives. Variables that related to increasing the electrification ratio in Madura Island is number of electricity customer, number of demand, electrification ratio and social and politic aspect. While those variables related to identify the projected electricity demand in Madura Island is income per capita, total demand in an area, power plant capacity and power requirement. 
TABLE 1 .

RESEARCH VARIABLE

\begin{tabular}{lll}
\hline \hline \multicolumn{1}{c}{ Research Objective } & & Variable \\
\hline $\begin{array}{l}\text { Increasing the } \\
\text { electrification ratio in } \\
\text { Madura Island }\end{array}$ & $\bullet$ & Number of Demand \\
& - & Electrification Ratio \\
& & Cumber of electricity \\
& - & Social and Politics \\
\hline $\begin{array}{l}\text { Identify the projected of } \\
\text { electricity demand on the }\end{array}$ & $\bullet$ & Income per Capita \\
Madura Island & - & Electrification Ratio \\
& $\bullet$ & Number of Demand \\
& $\bullet$ & Capacity of Electricity \\
& & Production \\
& $\bullet$ & Power Requirements \\
& $\bullet$ & Power System Capacity \\
\hline \hline
\end{tabular}

\section{Causal Loop Diagram}

Model development aims to knowing behavior pattern and relation between each variable which is determining the suitability model in real life. Causal loop diagram is a diagram that aids in visualizing how different variables in a system are interrelated. After the variables were identified, we develop the model to identify behavior pattern and relation between each of variables. Implementation of model development can be seen in figure 2.

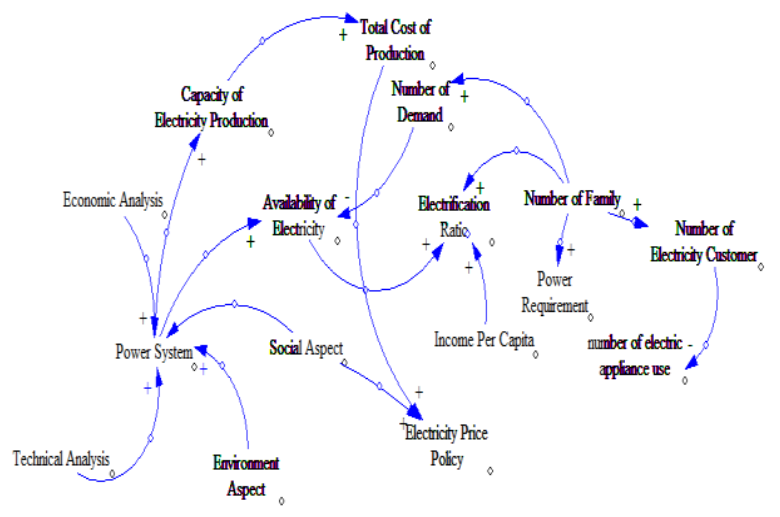

Figure 2. Causal Loop Diagram

\section{Stock and Flow Diagram}

Stock and flow diagrams provided a richer visual language than causal loop diagram. We need a technique that enables us to create a business prototype of the system that allow us to explore its behavior and to test the effect of changes to the system's structure and the policies governing its behavior.

Electricity demand was very important factor in power plant planning. By knowing the number of power need in an area, it can used to calculate how many power need in that area. Figure 3 shows the power need in each regency in Madura Island. Which is Bangkalan Regency, Pamekasan Regency, Sampang Regency and Sumenep Regency. The main factor that influenced growth of electricity demand in an area was number of electricity customer. In this flow model, electricity customer classified by their group rates, which is $450 \mathrm{kVA}, 900$ $\mathrm{kVA}, 1300 \mathrm{kVA}$. Based on the model, average of electricity demand growth is $9 \%$.

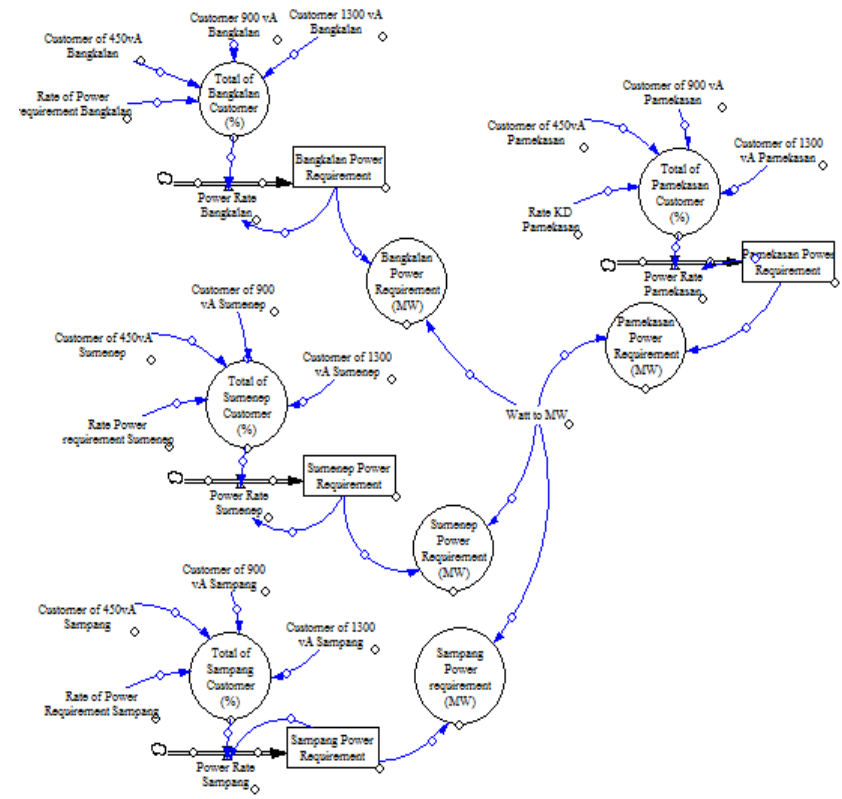

Figure 3. Stock and Flow Diagram

\section{E. Validation}

Validation is a process that determining are model was represented the real system or not. Data will valid if Mean comparison E1 is not more than $5 \%$ and error variance is not more than $30 \%$. The result can be seen in table 2 and table 3 . This validated data would be used to develop the scenario.

TABLE 2.

MEAN COMPARISON OF ELECTRICITY DEMAND

\begin{tabular}{ll}
\hline \hline \multicolumn{1}{c}{ Mean Comparison } & \multicolumn{1}{c}{ Valid E1 $\leq 5 \%$} \\
\hline Bangkalan Regency & $1 \%$ \\
Sampang Regency & $0.95 \%$ \\
Pamekasan Regency & $1.06 \%$ \\
Sumenep Regency & $1.52 \%$ \\
\hline \hline
\end{tabular}

TABLE 3.

ERROR VARIANCE OF ELECTRICITY DEMAND

\begin{tabular}{ll}
\hline \hline \multicolumn{1}{c}{ Error Variance } & Valid E2 $\leq 30 \%$ \\
\hline Bangkalan Regency & $1.53 \%$ \\
Sampang Regency & $0.85 \%$ \\
Pamekasan Regency & $3.63 \%$ \\
Sumenep Regency & $2.89 \%$ \\
\hline \hline
\end{tabular}

\section{F. Scenario Development}

Base model was basic reference to develop scenario model for used to projecting the Madura Electricity demand. In developing scenario, it will divided in 2 ways of scenario. Which is structure scenario and parameter scenario. Structure scenario is used to analyze the electricity demand in Madura Island.

On base model, the average of electricity demand growth in Madura Island from 1992 until 2015 is 9\%, based on data from PT PLN. We used 1992 - 2040 as a range in time period. The reason why we choose 2040 as a final time is develop of power plant required 2-3 years, so counted from 2017 added with power plant life time. For pessimistic scenario, the growth will not change. The result of pessimistic scenario can be seen in figure 4 . For 
optimist scenario, we projected the growth of electricity demand in Madura Island is $12 \%$ a year. This number based on survey from PT PLN East Java Distribution and data survey, which is taken from top average value of electricity demand. The result can be seen in figure 5. For most likely scenario, the average of electricity demand growth is $10 \%$ a year. This data taken from PT PLN and data survey, which is taken from top average value of electricity demand. Result of most likely scenario can be seen in figure 6.

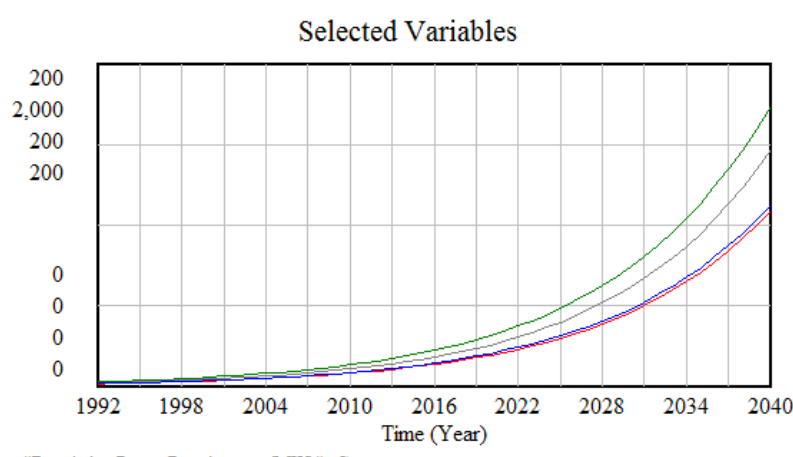

"Bangkalan Power Requirement (MW)" : Current "Pamekasan Power Requirement (MW)" : Curren "Sampang Power requirement (MW)" : Current
"Sumenep Power Requirement (MW)" : Current

Figure 4. Pessimistic Scenario Result

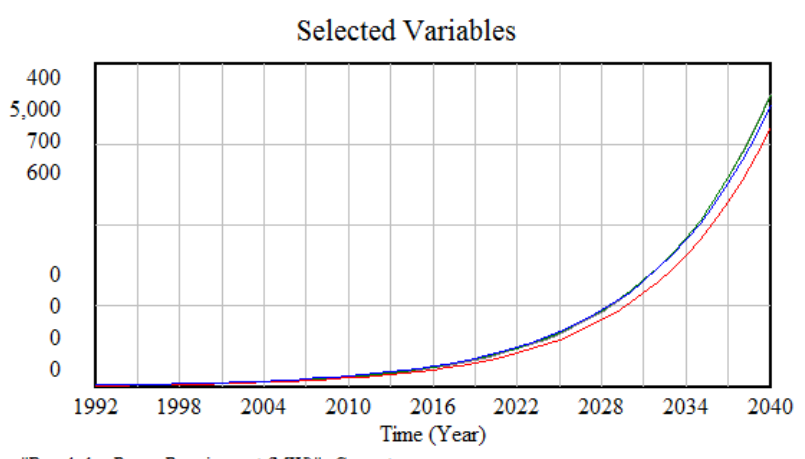

"Bangkalan Power Requirement (MW)" : Current "Pamekasan Power Requirement (MW)" : Current "Sampang Power requirement (MW)" : Current

Figure 5. Optimistic Scenario Result

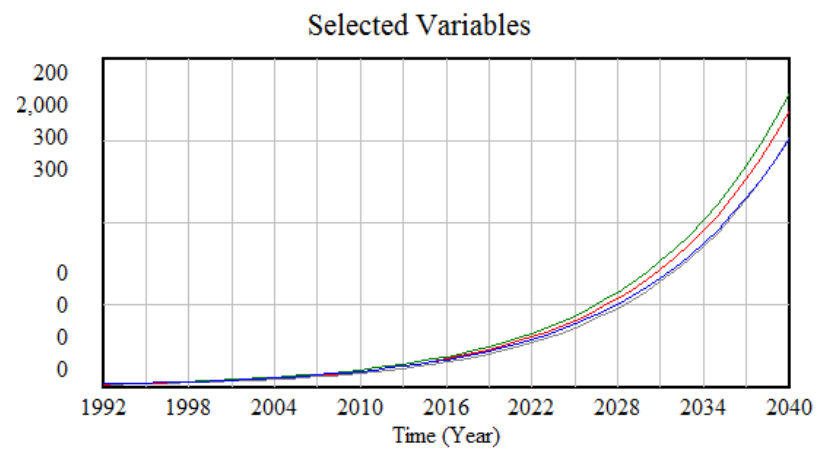

"Bangkalan Power Requirement (MW)" : Current

"Pamekasan Power Requirement (MW)": Curren

"Sumenep Power Requirement (MW)" : Current

Figure 6. Most Likely Scenario Result

\section{G. Power Plant Capacity Planning}

There were a few factors that must to be concerned in planning power plant capacity. Such as peak load in each region and reserve margin. Reserve margin is power plant spare against peak load on each region and it represented with percent $(\%)$. Based on power demand that has been calculated before and reserve margin $20 \%$ (http://www.pln.co.id) then we can plan power plant capacity in Madura Island. The model and simulation result can be seen in figure 7 and 8 .

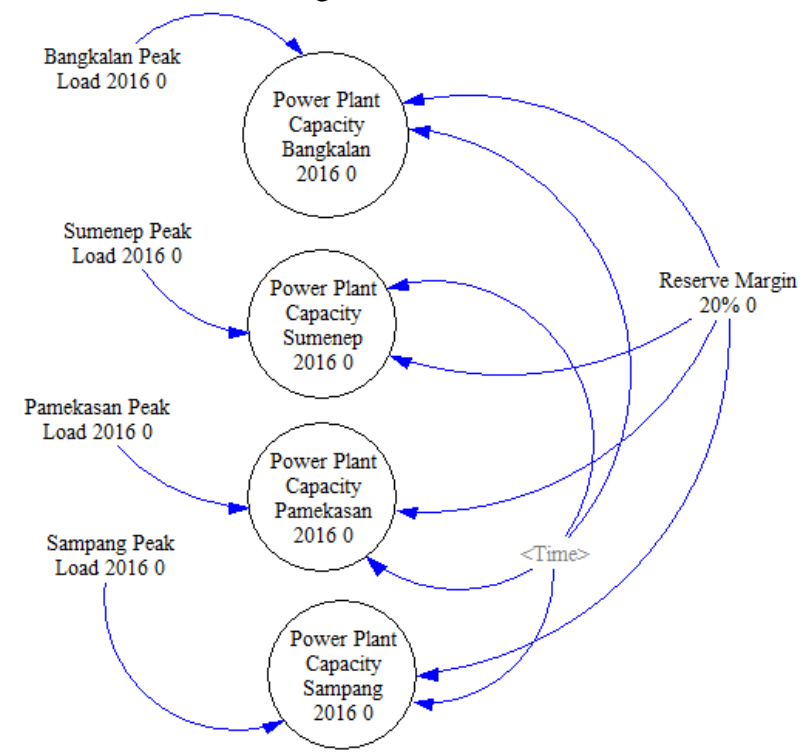

Figure 7. Power Plant Capacity Planning

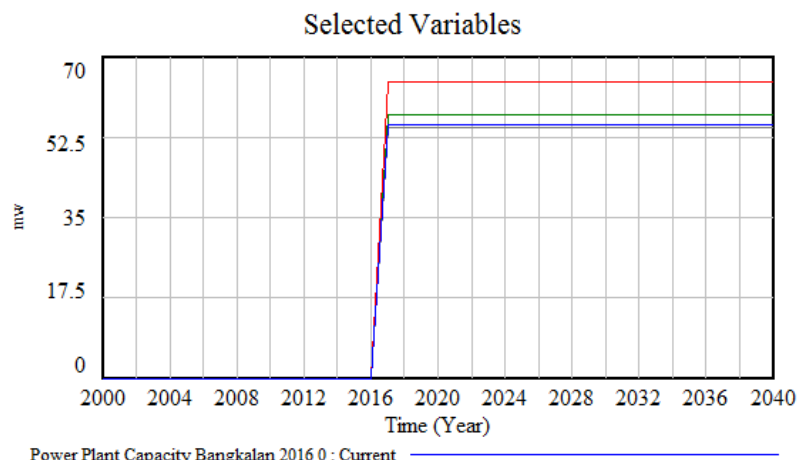

Power Plant Capacity Pamekasan 2016 0: Current

Power Plant Capacity Sampang 20160 : Current

Power Plant Capacity Sumenep 20160 : Current

Figure 8. Simulation Result

\section{CONCLUSION}

A good planning is a must for develop a new power plant in a region. Madura Island is kind of rare case because of some non-technical aspect should be considered in order to build a new power plant. Based on study that have been done, it can be concluded that:

- Of the model can be seen that the growth of electricity demand in Madura Island is $9 \%$

- Pamekasan regency has the highest number of electricity demand

- Based on model, we can projected the electricity demand in 2016 for Pamekasan regency is $129 \mathrm{mw}$, Bangkalan regency is $14 \mathrm{mw}$, Sampang regency is $21 \mathrm{mw}$ and Sumenep regency $17 \mathrm{mw}$.

In order to raising Madura's electrification ratio, PT PLN must have a good capacity plan. Based on the scenario development in 2040, PT PLN must supply 
231.64 mw. This result taken from peak load each region added with reserve margin $20 \%$.

Based on the research in the line 1,2, and 3 there are suspects of seepages and fracture consists of air. The embankment of these three line can be considered less worthy or less secure so that have high potency of landslide. Meanwhile, fourth line is suspected no fracture or seepage. Therefore these embankment of fourth line still feasible or in a good condition.

\section{REFERENCES}

[1] Sosrodarsono, S.,1985. Perbaikan dan Pengaturan Sungai, Pt. Pradnya Paramita, Jakarta.

[2] Aitsebaomo, F.O., O. Adeyami, and H.A Quadri. 2013."Electromagnetic Survey of Erosion in Awba, Ibadan Nigeria Embankment Dam". International Journal of Engineering and Science, Vol. 3, Issue 3, pp 01-05.

[3] Hardiyatmo, Hary Christadi, 2006. Penangangan Tanah Longsor dan Erosi. Gadjah Mada University Press, Yogyakarta.

[4] Balai Besar Wilayah Sungai Brantas .2011. www.pu.go.id/uploads/services/2011-11-30-11-37-29.pdf.

[5] Mainali, Ganesh. 2006. Monitoring of Tailing Dams with Geophysical Methods. Thesis. Lulea University of Technology.

[6] Warnana, Dwa Desa. 2008."Identifikasi Scouring sebagai Potensi Kelongsoran Tanggul Sungai Bengawan Solo Berdasarkan Survei GPR (Studi Kasus Desa Widang, Kabupaten Tuban)”. Jurnal Fisika dan Aplikasinya, Vol.4, No,2.

[7] Mori, Guido. 2009. The Use of Ground Penetrating Radar and Alternative Geophysical Technique for Assessing Embankments and Dykes Safety. Doctoral Thesis. Department of Earth and Geoenvironmental Science, University of Bologna.

[8] Sjodahl, Pontus.2006. Resistivity Investigation and Monitoring for Detection of Internal Erosion and Anomalous Seepage in Embankment Dams. Doctoral Thesis. Engineering Geology, Lund University : Sweden.

[9] Realita, Arie. 2016. Aplikasi Metode Very Low Frequency Electromagnetic Untuk Mitigasi Bencana Longsor Di Area Tanggul Sungai Brantas Mojokerto. Tesis Magister, Institut Teknologi Sepuluh Nopember, Surabaya. 